\title{
КОНТРОЛЬ ЧИСТОТЫ И БЕЗОПАСНОСТИ ФАРМАЦЕВТИЧЕСКИХ ПРЕПАРАТОВ НА ПРИМЕРЕ ПРОИЗВОДНОГО (-)-ИЗОПУЛЕГОЛА, ОБЛАДАЮЩЕГО АНАЛЬГЕТИЧЕСКОЙ АКТИВНОСТЬЮ
}

Ластовка А.В. ${ }^{1,2}$, Фадеева В.П. ${ }^{1,2}$, Ильина И.В. ${ }^{1}$, Рогачев А.Д. ${ }^{1,2}$, Волчо К.П. ${ }^{1}$, Салахутдинов Н.Ф., ${ }^{1,2}$

${ }^{1}$ ФГБУН Новосибирский институт органической химии им. Н.Н. Ворожцова СО РАН, Новосибирск, Россия

${ }^{2}$ Новосибирский национальный исследовательский государственный университет, Новосибирск, Россия nast.lastovka@gmail.com

DOI: 10.26902/ASFE-11_70

Методики контроля чистоты и безопасности лекарственных средств, описанные в Фармакопеи РФ, перестают удовлетворять постоянно изменяющимся требованиям к качеству физиологически активных веществ (ФАВ), фармацевтических субстанций и лекарственных препаратов, поэтому необходимо создание новых и совершенствование уже существующих методик, что является актуальной задачей современного фармацевтического анализа.

В отделе медицинской химии Новосибирского института органической химии им. Н.Н. Ворожцова СО РАН было получено новое производное монотерпеноида (-)-изопулегола $(2 R, 4 R, 4 \mathrm{a} R, 7 R, 8 \mathrm{a} R)-4,7$-диметил-2-(тиофен-2-ил)октагидро-2H-хромен-4-ол (1) (рис. 1), которое сочетает высокую анальгетическую активность в тестах висцеральной боли и низкую острую токсичность, имеет эффект пролонгированного действия при пероральном введении.<smiles>CC1CCC2(C)C(c3cccs3)CC(C)(O)C2C1</smiles>

Рис. 1. Структурная формула (1) (2R,4R,4aR,7R,8aR)-4,7-диметил-2-(тиофен-2ил)октагидро-2Н-хромен-4-ола (производное монотерпеноида (-)-изопулегола, производное 2Н-хромена, фармацевтический агент, физиологически активное вещество)

Совершенно очевидно, что фармацевтические продукты от ФАВ до готовой лекарственной формы должны быть наиболее полно охарактеризованы комплексом физикохимических методов. Контроль качества рассматриваемого ФАВ включал исследование физико-химических свойств [1]; разработку и валидацию методики идентификации технологических примесей и определения содержания действующего вещества методом ВЭЖХ-УФ [2]; разработку и валидацию методики определения остаточных органических растворителей методом ГХ-ПИД [3]; установление содержания элементных примесей методом МП-АЭС. Для построения фармакокинетического профиля были разработаны и валидированы четыре биоаналитические методики определения ФАВ в плазме и цельной крови животных методом ВЭЖХ-МС/МС в сочетании с экстракцией сухого пятна матрицы и экстракции на модифицированном целлюлозном носителе [4].

В результате разработаны и валидированы методики контроля качества нового физиологически активного вещества и, на основе полученных данных, создан стандартный образец предприятия.

\section{Список литературы}

1. Ластовка А.В., Фадеева В.П., Ильина И.В., Курбакова С.Ю., Волчо К.П., Салахутдинов Н.Ф. Исследование физико-химических свойств и разработка методики количественного определения $(2 \mathrm{R}, 4 \mathrm{R}, 4 \mathrm{aR}, 7 \mathrm{R}, 8 \mathrm{aR})-4,7-$ диметил-2-(тиофен-2-ил)октагидро-2Н-хромен-4-ола, обладающего высокой анальгетической активностью // Зав. лаб. Диагностика материалов. 2017. Т. 83. № 10. С. 11-17.

2. Ластовка А.В., Фадеева В.П., Ильина И.В., Салахутдинов Н.Ф. Аналитический контроль субстанции производного (-)-изопулегола - соединения с анальгетической активностью - по показателям “технологические примеси” и “действующее вещество” // Хим.-фарм. журн. 2020. Т. 54. № 2. С. 30-35.

3. Ластовка А.В., Яковлева Е.Ю., Коллегов В.Ф., Фадеева В.П., Салахутдинов Н.Ф. Определение остаточных органических растворителей методом газовой хроматографии в субстанции $(2 \mathrm{R}, 4 \mathrm{R}, 4 \mathrm{aR}, 7 \mathrm{R}, 8 \mathrm{aR})-4,7-2 и м е т и л-2-$ (тиофен-2-ил)октагидро-2Н-хромен-4-ол, обладающей анальгетической активностью // Зав. лаб. Диагностика материалов. 2018. Т. 84. № 9. С. 13-20.

4. Lastovka A.V., Rogachev A.D., Il'ina I.V., Kabir A., Volcho K.P., Fadeeva V.P., Pokrovsky A.G., Furton K.G., Salakhutdinov N.F. Comparison of dried matrix spots and fabric phase sorptive extraction methods for quantitation of highly potent analgesic activity agent (2R,4aR,7R,8aR)-4,7-dimethyl-2-(thiophen-2-yl)octahydro-2H-chromen-4-ol in rat whole blood and plasma using LC-MS/MS // J. Chromatogr. B. 2019. V. 1132. P. 121813 